\title{
Transport, Poverty and Agrarian Change in Africa: Models, Mechanisms and New Ways Forward
}

\section{Aaron deGrassi}

\section{Introduction}

Nearly every major study of African agriculture states that the lack of quality roads is one of, if not the, major constraint to agricultural input and output markets, and hence productivity growth and poverty alleviation. Road projects are some of the largest funded donor projects in Africa, and the largest cause of resettlement. And yet there is surprisingly little rigorous, empirical research dealing precisely with the multiple links between rural transport, poverty, and agrarian change in Africa.

\section{Conventional wisdom: more roads mean more development}

The argument for building more roads for agricultural growth hinges on reducing costs of inputs and increasing prices received for crops (Venables and Limão 1999; Crawford et al. 2003). For example, Hazell (2004: 11) notes:

Today if you look at road density in Africa it is a tiny fraction of what India had in the 1950s before its own green revolution. Most farms are just not connected to the market. Transport costs are horrendous. Fertilizer costs four or five times the world price for most Africans.

Transport has long been seen as key to development, and, previously, colonial exploration, conquest and extraction. Development organisations suggest Africa's "tragedy" of "bad geography" justifies significant interventions (Platteau 1996). Early postwar development emphasised capital investments in infrastructure, but when this failed to deliver, the focus shifted to basic needs. By the 1980s and 1990s, infrastructure again received emphasis after macroeconomic liberalisation failed to elicit the expected supply response.

Before the 1980s, transport projects focused on physical construction in a single country, agency, and/or mode. Since the 1980s, African transport systems have undergone privatisation, liberalisation, creation of autonomous road funds, and implementation of user-fees (road charges) (Mwase 2003). Slowly, attention is increasing on labourintensive construction, particularly with food-, cash- or inputs-for-work. There is a general shift from roads to "integrated rural accessibility", which involves, inter alia, decentralising road construction

\section{Figure 1: World Bank Lending to Transport in Sub-Saharan Africa}

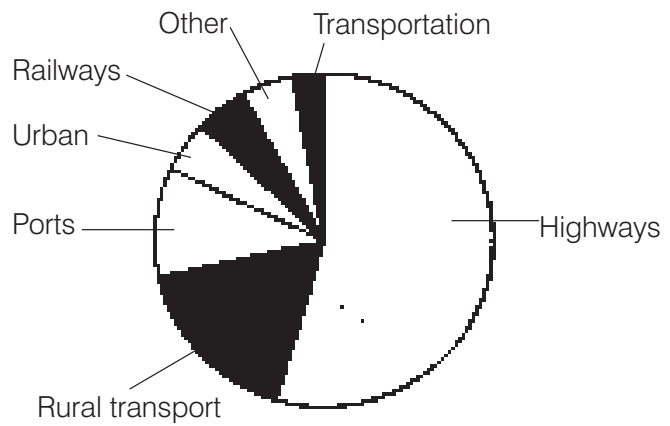

Source: World Bank (1999: 145)

IDS Bulletin Vol 36 No 2 June 2005 (C) Institute of Development Studies 
and maintenance (Zambia), intermediate means of transport (Uganda, Ghana), gender and issues of mobility (Porter 2003), though funding remains a fraction of highway finance (Figure 1).

Conventionally, road investments were guided by relatively crude cost-benefit analysis or cost effectiveness measures that emphasised consumer over producer surplus, and were based on models designed for urban, industrialised contexts (van de Walle 2002). Though "social" benefits and costs in some form - for example, higher school attendance - have been recognised for over half a century, they have only been narrowly conceptualised, poorly measured, and sparsely integrated into projects and policies (World Bank 1999; Howe 2003). ${ }^{1}$ Prevailing techniques ignored or underestimated the benefits of improving transport in remote, rural areas, and were primarily aimed at maximising aggregate economic returns. Budgetary allocations between and within infrastructure sectors often did not prioritise poverty alleviation, and were rarely informed by balanced and thorough evaluations. Where evaluations existed, they often served as rubber stamps, lacking independence and public access. Consequently, a 1997 World Bankcommissioned review (Gannon and Liu 1997: vi, viii) noted:

The short-term and long-term distributive impacts of transport projects, particularly on low-income groups, are not well understood ... There are no guiding principles for, or systematic approaches to, poverty issues in transport sector operations.

Recently, interest has grown in how improved transport can reduce poverty by facilitating agricultural development. However, empirical and theoretical studies of rural roads and their relation to agriculture and poverty are dominated by a limited set of economic methodologies and concepts (e.g. Ahmed and Donovan 1992). Conceptually studies draw from transaction cost economics and, earlier, from classical economic geography (e.g. Wanmali and Islam 1997; Venables and Limão 1999). ${ }^{2}$ Methodologically common are relatively simplistic juxtapositions of high-road density, foodsurplus Asia and low-road density, food-deficit Africa. A second approach, illustrated by Fan et al. (2000), involves macrolevel econometric modelling to examine possible correlations between poverty reduction and investment in rural roads. Third are microlevel econometric models examining correlations between road density or distance to roads and agricultural productivity growth or adoption of technology (e.g. Obare et al. 2003).

Transport research - as well as planning, policy and projects - has rarely involved popular participation. A search of the over 500 references on www.transport-links.org yields only a few dealing with participatory approaches to transport. Similarly, the World Bank has only produced a few transport papers dealing with participation. The participatory approaches that do exist suffer from assumptions of relatively homogenous communities and harmonious deliberation.

\section{New perspectives}

Prevailing concepts and methods miss highly important social, economic, political and cultural dimensions that are critical for understanding and improving transport projects and policies, and their implementation and impacts on food security and economic growth. For example, despite longstanding and overwhelming evidence of transportdisease links (Hogbin 1985), HIV/AIDS is ignored in most major transport documents. Few African countries have transport policies; of those that do, almost none address HIV/AIDS. Only in 2003 did the Bank itself publish guidelines and a framework for Africa.

Transport development may have contradictory effects on efforts to reduce poverty through agricultural growth. Rising productivity may not raise rural wages if new roads increase labour supplies. Increased food production may not lower prices for poor consumers if improved transport increases food exports. And extra income may not be multiplied into local jobs if it is spent on imported commodities (e.g. clothing or rice). Other possible effects of transport development include:

- increasing the extent and speed of disease transmission

- increasing out- or in-migration

- reducing off-road markets

- increasing competition by imports

- usurpation of local resources and markets

- strengthening authoritarian military-political control

- facilitating enclaves of resource extraction (of timber, minerals, etc.) 
- increasing pollution, accidents, or land degradation

- increasing class and gender inequality

- forcing displacement

- eliminating poor petty transporters

- increasing susceptibility to oil price swings

- displacing roadside markets by restricting marketing to centralised facilities

- reducing intermediate transport upon which the poor depend

- displacing food with export crops

- endangering poor porters and walkers with highspeed traffic

- increasing land values and thereby worsening access for the poor, women, migrants, youths or others.

Going beyond conventional approaches, we can improve understanding and management of such dynamics - often indirect, complex, and interlinked - by incorporating insights from history, geography, anthropology and political economy about how "space", and hence transport, is constituted by interlinked social, economic, political and cultural relations (Massey 1994; Lee and Wills 1997; Peet 1998). The following sections discuss examples, focusing on the politics of investment, uneven development, political symbolism, and social relations.

\subsection{Politics of investment}

Planning transport investment is rarely a purely rational process; economic models guiding investment are often selective, and in practice overridden by political considerations. Early on, transport was a means of obtaining possession of colonies - 'coloniser c'est transporter', remarked Belgium's brutal King Leopold.

There is a great dearth of information about the institutional and ownership structures of transport networks, which should raise concern given the sector's massive financing (a current Tanzanian transport project, for example, involves US $\$ 2.6 \mathrm{bn}$ ). In the last several decades, US $\$ 40$ bn has been spent on transport projects involving the World Bank in Africa. ${ }^{3}$ Despite frequent media reports of corruption in transport, few people ever study the issue. Firms, donors and officials benefiting from such corruption have an interest in propagating technical, apolitical models of transport planning and impact.

Transport projects are shaped by their heavy reliance on specialised foreign consultants, who often have a relatively poor understanding of local contexts. Since 2000, the World Bank alone has spent almost US $\$ 3$ bn on consultants for transport projects in Africa. ${ }^{4}$ Transport consultancies range from specialised research institutes like TRL Limited, to major engineering groups such as China Road and Bridge Corporation, to the major generalist consultants like PricewaterhouseCoopers. Conventional wisdoms are reproduced in specialised periodicals such as Transport Reviews and Transportation Research Record, and at meetings such as the World Road Congress, but debates are rarely open to wider scrutiny and discussion.

\subsection{Uneven development}

If we move away from the illusion that investment is always guided by objective assessment and rational planning, we can see how politics at various scales, though rarely acknowledged or examined, strongly shape the amount, structure and location of transport, and are also affected by it. The result is a highly uneven pattern of development and transport (Smith 1984; Castree et al. 2004; Amanor, this IDS Bulletin).

Roads can be both a response to political pressure, as well as a means for it. Improved transport may improve access to bureaucratic officials and political representatives, and hence help increase downward accountability. Alternatively, disrupting traffic is a visible and financially threatening protest tactic. Roads can also be used for patronage - through investments, allocation of construction and maintenance contracts, and by rewarding local clients with the ability to use road blocks to extract bribes. Central elites may misuse notions of externalities and economies of scale to prevent decentralised road administration, when in fact democratic decentralisation combined with regional coordination would suffice (deGrassi 2003).

Transport is also shaped by large-scale geopolitical battles (often targeting the highest-value networks). For example, apartheid opponents attempted to restructure routes (and hence revenues) away from South Africa. Rebels in northern Côte d'Ivoire have blocked transport of cotton southward. And transport infrastructure was a key target during the wars in Mozambique, Democratic Republic of the Congo, Angola and elsewhere.

Politics shape local level access to new roads, goods and employment. Routes between rival areas 
can decline. Alternatively, changes in transport can modify the pattern of economic opportunities and thereby reconfigure political relations between men and women, poor and rich, old and young, migrant and local. Such changes can give leverage to previously subjugated groups, or conversely, increase the political dominance of the rich and powerful as they capture the largest gains from new transport.

Increased competition does not inevitably follow transport projects - expansion may open up new frontiers that grant windfall monopoly profits. As resource bases decline or new routes open, what were once thriving centres can become remote backwaters (as in the case of many off-road markets in Nigeria isolated by new roads constructed with petroleum revenues). With ports for example, Tema has been surpassed by Takoradi, Grand Bassam by Abidjan, St Louis by Dakar, and Lindi by Mtwara. A continual cycle exists in which new transport raises productivity until markets are saturated, necessitating further cost-reducing investments in transport.

\subsection{Political symbolism}

Transport is loaded with potent symbolism. Road projects - with expensive, bright, large, heavy and loud equipment - can garner state legitimacy. Road construction often commences before elections and recedes shortly thereafter. Donors too like timebound, easily funded show pieces. Rural people may internalise such preferences, complicating participatory research and opinion surveys. Bicycles, motorcycles and ox-carts also frequently have symbolic connotations of wealth, masculinity and/or social status.

Transport was both an icon and a tool for Cecil Rhodes in his quest for a railroaded empire from "Cape to Cairo". Transport could also mark "the revolution", as with the "Great Uhuru [Freedom] Railway" from Tanzania to Zambia, built by the Chinese in the 1970s (and regarded in Washington as the "Red Railway"). Transport is a social prism, as in the classic book The Road, by the exiled Nigerian Nobel-laureate poet and playwright Wole Soyinka. And Ousmanne Sembene - the doyen of African film - has memorialised the 1947-8 strike by 20,000 workers on the Dakar-Niger rail line in his novel God's Bits of Wood. Recognising transport's symbolic dimension is therefore crucial to understanding the sector's dynamics.

\subsection{Social relations}

Social relations shape transport services, as well as access to, and need for, such services. Men own and control most transport, while women and children do disproportionately more porterage (particularly lower-paid and informal sorts). Transport services are rarely perfectly free and competitive, but rather significantly influenced by public control and regulations, and, in privatised systems, by transport unions, and oligopolies (sometimes kin-based) in certain areas or subsectors (petrol, auto-parts, etc.). Highly concentrated ownership structures can capture the gains from improved roads rather than passing them on to consumers. Farmer associations may be able to bargain for lower costs, but entail their own politics of inclusion. Transport construction, maintenance and services can be important sources of employment and income for highly skilled and unskilled people, both locals and migrants, yet little is known of employment conditions, nor how these shape transport structures, prices and access.

Access to transport is shaped by social and legal dynamics affecting daily mobility, travel, and longterm residence. An oft-cited example is the norm in some places against women riding bicycles. Likewise, "vulnerable" groups may be permitted to travel on local paths, but not on high-volume roads associated with social vices. Norms, however, vary with context, time and identity (including age, marital status, ethnic and religious background, class) and we need more research on how and why. Rather than being objective, natural or primordial, marginality is often created by biased investment, by stereotypes, and by social and political processes that restrict mobility and force people to move to, or remain in, marginal or remote areas (e.g. conflict, land tenure, ostracisation) (Tsing 1993). Improving physical transport will remain a superficial solution if these underlying inequities are not redressed.

Needs for travel are shaped by socially constructed obligations on productive and reproductive duties (e.g. water or fuelwood collection). Long-distance trips are often made for social purposes, such as visiting relatives, weddings, funerals, etc. (often with multiple, economic dimensions). Networking can occur during short and long journeys. Access to social services is arguably equally important for rural well-being and food security, but is less often mentioned in the agriculture literature. Only now is 
transport beginning to be analysed rigorously in relation to broader livelihoods.

Precisely because transport networks move value quickly, security is key. Relevant is Wilson's (2004: 544) description: 'roads are known places of ambush and assault, frequented by delinquents, terrorists, smugglers, drug-dealers; they are the places where deals are done with bad cops' (see also Fairhead 1993). Transport holding companies and networks play key roles in corruption and devastating conflicts involving high-value timber, mineral and oil resources (Global Witness 2003) - a link almost never addressed by mainstream transport and development organisations.

\section{Conclusion}

Efforts to reduce rural poverty in Africa by improving transport are constrained not just by

\section{Notes}

1. Measurement difficulties are rife, and social impacts may be subtle, long-term, and/or dependent on local contextual factors (fees, quality of service, etc.). See the conference on social benefits, available on www.transport-links.org/ transport_links/projects/ (accessed 17 February 2005).

2. The growing field of "new economic geography" has had little application to African agriculture and is arguably merely a repackaging of classical economic geography together with mathematic economics (Martin 1999).

\section{References}

Ahmed, R. and Donovan, C., 1992, 'Issues of infrastructural development: a synthesis of the literature', Occasional Paper 25, Washington, D.C.: International Food Policy Research Institute

Castree, N., Essletzbichler, J. and Brenner, N. (eds), 2004 'Symposium on David Harvey's The limits to capital - two decades on', Antipode, Vol 36 No 3: 401-549

Crawford, E., Kelly, V., Jayne, T.S. and Howard, J. (eds), 2003, 'Special issue on input use and market development in Africa', Food Policy, Vol 28 No 4: 277-419

deGrassi, A., 2003, 'Constructing subsidiarity, consolidating hegemony: political economy and agro-ecological processes in Ghanaian forestry', Environmental Governance in Africa Working Paper 13, Washington, D.C.: World Resources Institute physical conditions, but also by prevailing models, institutional structures and research paradigms and networks. Viewing transport as "basic" or "hard" infrastructure, in contrast to "soft" issues of health or education - as is common in much literature on African agriculture - leads to overly simplistic recommendations ("just build more roads") that downplay or ignore social and institutional factors that significantly shape transport management, use and impacts. Propagating technocratic notions of transport is, arguably, a political act itself. Greater participation and greater consideration of the multiple aspects of transport should lead to a more realistic assessment of how rural poverty and transport interact, the potential benefits and costs of specific changes in transport, and the opportunities for and obstacles to such changes.

3. World Bank Projects Database, available http://web.worldbank.org/WBSITE/EXTERNAL/PROJEC TS/ (accessed 17 February 2005).

4. World Bank Database of Contracts Awarded, available http://web.worldbank.org/WBSITE/EXTERNAL/PROJEC TS/ (accessed 17 February 2005).

Fairhead, J., 1993, 'Paths of Authority: Roads, the State and the Market in Eastern Zaire', in C. Hewitt de Alcantar (ed.), Real Markets, London: Frank Cass

Fan, S., Hazell, P. and Thorat, S., 2000, 'Government spending, agricultural growth, and poverty in rural India', American Journal of Agricultural Economics, Vol 82 No 4: 1038-51

Gannon, C. and Liu, Z., 1997, Poverty and Transport, Washington, D.C.: World Bank

Global Witness, 2003, The Usual Suspects: Liberia's Weapons and Mercenaries in Cote d'Ivoire and Sierra Leone, London: Global Witness

Hazell, P., 2004, 'Testimony', in United Kingdom Parliament, House of Commons, International Development Committee, DfID's Agricultural Policy, Seventh Report of Session 2003-04, HC602, London 
Hogbin, V., 1985, 'Railways, disease and health in South-Africa', Social Science and Medicine, Vol 20 No 9: 933-8

Howe, J., 2003, 'Inclusion of social benefits in transport planning - review of developing country experience', mimeo, www.transport-links.org/ (accessed 18 February 2005)

Lee, R. and Wills, J. (eds), 1997, Geographies of Economies, London: Arnold

Martin, R., 1999, 'The new "geographical turn" in economics: some critical reflections', Cambridge Journal of Economics, Vol 23 No 1: 65-91

Massey, D., 1994, Space, Place, Gender, Minneapolis: University of Minnesota Press

Mwase, N., 2003, 'The liberalisation, de-regulation and privatisation of the transport sector in subSaharan Africa', Journal of African Economies, Vol 12: 153-92

Obare, G.A., Omamo, S.W. and Williams, J.C., 2003, 'Smallholder production structure and rural roads in Africa: the case of Nakuru District, Kenya', Agricultural Economics, Vol 28 No 3: 245-54

Peet, R., 1998, Modern Geographic Thought, Malden: Oxford

Platteau, J.P., 1996, 'Physical infrastructure as a constraint on agricultural growth: the case of sub-Saharan Africa', Oxford Development Studies, Vol 24: 189-219
Porter, G., 2003, 'Spatio-temporal perspectives on the social benefits and costs of roads and road transport', mimeo, www.transport-links.org/ (accessed 18 February 2005)

Smith, N., 1984, Uneven Development: Nature, Capital and the Production of Space, Oxford: Basil Blackwell

Tsing, A.L., 1993, In the Realm of the Diamond Queen: Marginality in an Out-of-the-Way Place, Princeton: Princeton University Press

van de Walle, D., 2002, 'Choosing rural road investments to help reduce poverty', World Development, Vol 30 No 4: 575-89

Venables, A.J. and Limão, N., 1999, 'Geographical disadvantage: a Heckscher-Ohlin-von Thunen model of international specialization', Policy Research Working Paper 2256, Washington, D.C.: World Bank

Wanmali, S. and Islam, Y., 1997, 'Rural infrastructure and agricultural development in Southern Africa', Geographical Journal, Vol 163: 259-69

Wilson, F., 2004, 'Towards a political economy of roads', Development and Change, Vol 35 No 3: 525-46

World Bank, 1999, 'Managing the social dimensions of transport', Report 30421, Washington, D.C.: World Bank 